\title{
Pembinaan Pendidikan Karakter Akhlak Mulia Melalui Ekstrakurikuler
}

\author{
MUALIMIN \\ Universitas Lampung, Jl. Prof. Dr. Soemantri Bojoneforo No.1 Kota Bandar Lampung \\ Hp: 081379163615 Email: saudinsaudin@yahoo.co.id
}

\begin{abstract}
Abstrak: Program pembinaan pendidikan karakter akhlak mulia bertujuan untuk mengembangkan pemahaman siswa mengenai nilai-nilai moral sehingga anak akan mampu berpikir, berperasaan dan berperilaku sesuai dengan akhlak mulia. Penelitian ini mengkaji tentang implementasi program pembinaan pendidikan karakter akhlak mulia siswa melalui kegiatan ekstrakurikuler di SDN 2 Palapa Kecamatan Tanjung Karang Pusat Kota Bandar Lampung. Dengan rumusan masalah bagaimana implementasi program pembinaan pendidikan karakter akhlak mulia siswa melalui kegiatan ekstrakulikuler di SDN 2 Palapa dan faktorfaktor apa saja yang mendorong dan menghambat dalam pengimplementasian program pembinaan pendidikan karakter akhlak mulia siswa di SDN 2 Palapa. Penelitian ini termasuk penelitian deskriptif dengan pendekatan kualitatif, sumber informasi dalam penelitian ini adalah kepala sekolah, guru, komite, dan siswa disekolah SDN 2 Palapa. Teknik pengumpulan data yang digunakan dalam penelitian ini adalah observasi, wawancara, dan dokumentasai. Berdasarkan hasil penelitian, implementasi program pembinaan pendidikan karakter akhlak mulia siswa melalui kegiatan ekstrakurikuler dengan kegiatan seperti: penerangan bahaya narkoba, outbond bagi siswa, kebersihan dan kesehatan, memperingati tahun baru islam, lomba, bercerita mengarang ketauladanan nabi, dan pramuka. Dengan demikian dapat disimpulkan implementasi program pembinaan pendidikan karakter akhlak mulia siswa melalui kegiatan ekstrakurikuler di SDN 2 Palapa Kecamatan Tanjung Karang Pusat Kota Bandar Lampung dapat merubah nilai-nilai akhlak siswa terhadap sesama teman, akhlak siswa terhadap guru, akhlak siswa terhadap lingkungan, tanggung jawab siswa terhadap tugas, kepatuhan siswa terhadap kerapihan dan tata tertib.
\end{abstract}

Kata kunci: program pembinaan, pendidikan karakter mulia, ekstrakurikuler.

\section{PENDAHULUAN}

Kemajuan suatu bangsa dipengaruhi oleh akhlak masyarakatnya. Bangsa yang masyarakatnya menjunjung tinggi dan membiasakan akhlak mulia serta diikuti dengan penguasaan ilmu pengetahuan dan teknologi yang tinggi akan berpotensi menjadi bangsa yang maju, yang akan diperhitungkan dalam kancah dunia internasional. Sejarah telah mencatat bahwa kehancuran peradaban suatu bangsa disebabkan oleh akhlak warga negaranya yang tidak terpuji. Menurut Sofwan Sauri (2010: 1), keruntuhan sebuah bangsa ditandai dengan semakin lunturnya tata nilai dan karakter bangsa tersebut.

Berdasarkan visi pembangunan nasional sebagaimana tertuang dalam RPJP (2005-2025), visi jangka panjang yang akan diwujudkan adalah 
menjadikan bangsa Indonesia yang mandiri, maju, adil, dan makmur serta tujuan lainnya adalah untuk mewujudkan masyarakat berakhlak mulia, bermoral, beretika, berbudaya, dan beradab berdasarkan falsafah pancasila. Dengan memperkuat jati diri dan karakter bangsa melalui pendidikan bertujuan untuk membentuk manusia yang bertaqwa kepada tuhan yang maha Esa, mematuhi peraturan hukum, memelihara kerukunan internal dan antarumat beragama, melaksanakan interaksi antarbudaya, mengembangkan modal sosial, menerapkan nilai-nilai luhur budaya bangsa, dan memiliki kebanggaan sebagai bangsa Indonesia dalam rangka menetapkan landasan spritual, moral, etika, dan pembangunan bangsa (Ali, 2009: 35).

Perilaku akhlak mulia pada siswa hendaknya menjadi perilaku sehari-hari bukan hanya muncul pada saat-saat tertentu, misalnya pada bulan ramadhan atau ketika di dalam masjid saja. Untuk menjadikan perilaku akhlak mulia menjadi perilaku dalam kehidupan sehari-hari, maka pendidikan akhlak mulia di sekolah sangat penting bagi anak. Bangsa yang Indonesia dibangun berdasarkan falsafah luhur pancasila yang mana di dalamnya menjunjung tinggi nilai-nilai akhlak mulia, yang dijadikan landasan falsafah dalam kehidupan bernegara, berbangsa, dan bermasyarakat untuk meningkatkan keimanan dan ketaqwaan serta akhlak mulia bagi seluruh anak bangsa.

Membangun karakter akhlak mulia dan watak bangsa mutlak diperlukan, bahkan tidak bisa ditunda, melalui sumber nilai-nilai akhlak mulia berdasarkan nilai-nilai agama, pancasila, budaya serta tujuan nasional pendidikan itu sendiri. Dasar yuridis amanat untuk mewujudkan akhlak mulia terdapat dalam undang-undang Dasar 1945 yang telah di amandemankan yang mana mengamanatkan pemerintah untuk mengusahakan dan menyelenggarakan satu sistem pendidikan nasional yang meningkatkan keimanan dan ketaqwaan kepada tuhan yang maha Esa, serta akhlak mulia dalam rangka mencerdaskan kehidupan bangsa.

Amanat itu juga dioprasionalkan dalam undang-undang sistem pendidikan nasional nomor 20 tahun 2003 dalam tujuan pendidikan nasional BAB II pasal 3, yaitu: "Pendidikan nasional berfungsi mengembangkan kemampuan dan membentuk watak serta peradaban bangsa yang bermartabat dalam rangka mencerdaskan kehidupan bangsa, bertujuan untuk mengembangkan potensi peserta didik agar menjadi manusia yang beriman dan bertakwa kepada Tuhan Yang Maha Esa, berakhlak mulia, sehat, berilmu, cakap kreatif, mandiri dan menjadi warga Negara yang demokratis serta bertanggung jawab" (Nata, 1997: 12).

Dalam Permendiknas nomor 39 tahun 2008 tentang pembinaan kesiswaan disebutkan bahwa tujuan pembinaan kesiswaan antara lain adalah "Menyiapkan siswa agar menjadi warga masayarakat yang berakhlak mulia, demokratis, menghormati hak-hak azasi manusia dalam rangka mewujudkan masyarakat madani (civil society)." Dalam keputusan menteri pendidikan nasional RI Nomor 125/U/2002 tentang kalender pendidikan dan jam belajar efektif di Sekolah, Bab V pasal 9 ayat 2, dinyatakan bahwa: "Pada tengah semester 1 dan 2 sekolah melakukan kegiatan olahraga dan seni (Porseni), Karyawisata, lomba kreativitas atau praktek pembelajaran yang bertujuan untuk mengembangkan bakat, kepribadian, prestasi, dan kreativitas siswa dalam rangka mengembangkan 
pendidikan anak seutuhnya" (Aqib \& Sujak, 2011: 70).

Pada lampiran Keputusan Menteri Pendidikan Nasional Nomor 125/U/2002 tanggal 31 Juli 2002 disebutkan $\square$ liburan sekolah atau madrasah selama sebulan diisi dan dimanfaatkan untuk melaksanakan berbagai kegiatan yang diarahkan pada peningkatan akhlak mulia, pemahaman, pemdalaman, dan amaliah agama termasuk kegiatan ekstrakurikuler lainya yang bermuatan moral? (Aqib \& Sujak, 2011: 70).

Pada dasarnya penanaman nilai, budi pekerti, ataupun karakter sebaiknya ditanamkan dalam berbagai lingkungan ekologis siswa, baik dari keluarga, sekolah maupun masyarakat. Sebagaimana Bronfenbrenner (dalam kepmendiknas direktorat jenderal manajemen pendidikan dasar dan menengah, 2010: 3) mengemukakan "Seseorang akan dipengaruhi oleh empat lingkungan yaitu mikrosistem, eksosistem, mesosistem, dan makrosistem". Lingkungan mikrosistem adalah lingkungan rumah (di dalam lingkungan keluarga). Lingkungan mesosistem adalah lingkungan lingkungan tetangga dan sekolah. Lingkungan ekosistem adalah lingkungan masyarakat yang mencakup RT, RW. Lingkungan makrosistem adalah lingkungan Negara, aturan yang mengatur, kebudayaan dan lain sebagainya. Dengan adanya empat lingkungan siswa tersebut, maka sebaiknya penanaman akhlak mulia pun diterapkan secara konsisten pada semua tataran.

Uraian diatas menunjukan bahwa pentingnya penyelenggaraan pendidikan yang membangun dan menumbuhkembangkan karakter atau akhlak mulia siswa disemua jenjang dan tingkat satuan pendidikan serta berbagai lingkungan ekologis siswa. Pendidikan akhlak mulia ini merupakan usaha bersama sekolah dan oleh karenanya perlu dilakukan secara bersama-sama oleh semua guru dan pimpinan sekolah, melalui semua mata pelajaran dan menjadi bagian yang tidak terpisahkan dari budaya sekolah.

Pembinaan pendidikan akhlak mulia telah dicanangkan oleh pemerintah melalui kementrian pendidikan nasional direktorat jendral menejemen pendidikan dasar dan menengah. Melalui kegiatan pembinaan akhlak mulia ini telah dipersiapkan suatu pedoman/program pembinaan akhlak mulia di sekolah dan dengan mengucurkan dana pembinaan bagi sekolah-sekolah, salah satu sekolahsekolah tersebut yang menerima bantuan pembinaan pendidikan karakter akhlak mulia adalah sekolah dasar negeri 2 Palapa Tanjung Karang Pusat.

Berdasarkan Kepmendiknas (2010: 4), menyebutkan bahwa fungsi pembinaan pendidikan karakter akhlak mulia ini adalah untuk pengembangan, perbaikan dan penyaringan. Fungsi pengembangan di sini agar siswa dapat mengembangkan perilaku yang baik sehingga dapat bersikap dan perilaku yang mencerminkan budaya dan karakter bangsa. Fungsi perbaiakan adalah untuk memperkuat pengembangan potensi siswa agar lebih bermartabat. Fungsi penyaring adalah agar siswa dapat menyaring bidayabudaya bangsa sendiri dan budaya bangsa lain yang tidak sesuai dengan nilai-nilai budaya dan karakter bangsa secara keseluruhan.

Tujuan pengembangan pendidikan akhlak mulia ini adalah agar kita sebagai pendidik dapat membantu mengembangkan potensi kalbu/nurani/afektif siswa sebagai 
manusia dan warganegara yang memiliki nilai-nilai budaya dan karakter bangsa, juga mengembangkan kebiasaan dan perilaku siswa yang terpuji dan sejalan dengan nilai-nilai universal dan tradisi budaya bangsa yang religius. Selain itu juga diharapkan pendidik dapat menanamkan jiwa kepemimpinan dan tanggungjawab siswa sebagai generasi penerus bangsa, mengembangkan kemapuan siswa menjadi manusia yang mandiri, kreatif, berwawasan kebangsaan. Pada akhirnya, kegiatan ini ditujukan untuk mengembangkan lingkungan kehidupan sekolah sebagai lingkungan belajar yang aman, jujur, penuh krerativitas dan persahabatan, serta dengan rasa kebangsaan yang tinggi dan penuh kekuatan.

Berdasarkan penjelasan diatas, ada beberapa alasan yang menjadi landasan dari penelitian ini. Pertama, dalam pelakasanaan pembinaan pendidkkan karakter akhlak mulia diperlukan suatu strategi untuk menentukan arah dan tindakan yang diinginkan waktu yang akan datang. Strategi atau cara mencapai tujuan dan sasaran dituangkan dalam program, kebijakan, kegiatan yang dilakukan. Kedua, masyarakat mendambakan siswa yang berakhlak mulia, orang tua berharap memiliki putra dan putri yang baik, antara lain taat menjalankan agamanya, jujur, disiplin, toleran, tidak cepat putus asa, bekerja/belajar keras, suka menolong, dan akhlak mulia lainnya. Ketiga, secara empiris program pembinaan karakter akhlak mulia ini menarik untuk dilakukan penelitian mengingat SD Negeri 2 Palapa sebagai peneriama bantuan kementrian pendidikan nasional melalui direktorat jendral menejemen pendidikan dasar dan menegah.

Permasalahan yang berkaitan dengan akhlak siswa disekolah dasar negeri 2 Palapa kecamatan Tanjung karang Pusat Kota Bandar Lampung, dimana masih ada perilaku yang tidak sewajarnya dilakukan oleh sebagian guru atau siswa, baik secara perorangan ataupun kelompok. Dari data prasurvey dalam mengimplimentasikan pembinaan akhlak mulia yang diadakan SD 2 Palapa pada tahun 2010-2011 terdapat peserta didik yang berprilaku tidak baik yaitu tidak sopan terhadap guru, kurang menghargai sesama teman, prilaku kurang peduli terhadap lingkungan, kurang tanggung jawab terhadap tugas, berkata kotor, suka bekerja sama ketika diadakan ujian, membuang sampah sembarangan dan makan daan minum sambil berdiri. Selain itu juga penulis mengadakan survey terhadap guru, permasalahan yang ditemukan bahwa masih ada siswa SD 2 Palapa yang berkata kotor didepan guru, belajar sambil bermain-main, makan dan minum sambil berdiri. Hal ini sesuai dengan hasil catatan wali kelas tentang pembinaan pembelajaran karakter bangsa SD Negeri 2 palapa ditemukan siswa yang belum berperilaku baik, lebih jelas lihat tabel berikut:

Tabel 1

Rekab buku catatan guru wali kelas terhadap perilaku siswa

\begin{tabular}{llll}
\hline No & \multicolumn{1}{c}{ Nama } & Kelas & \multicolumn{1}{c}{ Indikator Perilaku } \\
\hline 1 & Lintang & V.B & bermain lotre \\
\hline 2 & Iqbal Maulana & V.A & Menganggu temannya \\
\hline 3 & M.Wahyudi & VI.B & Sering bolos \\
\hline 4 & M.Haikal & VI.D & Nyanyi dikelas naik meja \\
\hline
\end{tabular}




\begin{tabular}{|c|c|c|c|}
\hline 5 & Ade Irma & V.A & Tidak membuat tugas \\
\hline 6 & Fananda Aurelia & V.A & Tidak membuat tugas dan ribut saat belajar \\
\hline 7 & Fani Tiara Putri & V.A & Sering malas membuat tugas \\
\hline 8 & Nurul Febriyana & V.A & $\begin{array}{l}\text { Buang sampah sembarangan dan lalai terhadap } \\
\text { tugas }\end{array}$ \\
\hline 9 & Reghina Elifia & V.A & Mengolok-olok temanya \\
\hline 10 & Risa Putri & V.A & Sering terlambat dan lalai terhadap tugas rumah \\
\hline 11 & Ade Anuggrah & V.A & Berkata kotor,jahil dan malas mengerjakan tugas \\
\hline 12 & Alif Praditya & V.A & Coret-coret meja, mengabaikan tugas (PR) \\
\hline 13 & Fitra Fauzi Hari & V.A & Berkata kotor, bermain dalam kelas saat belajar \\
\hline 15 & Yoanda Delangi & V.A & Coret-coret meja, tidak mengerjakan tugas rumah \\
\hline 16 & Zahara Zafira & V.A & Sering terlambat masuk kelas dan pemalas \\
\hline 17 & Sovi & VI.A & Suka menghina teman, buang sampah sembarangan \\
\hline 18 & Rizki Perdana & VI.A & Melawan ketiga ditegur guru, malas membuat tugas \\
\hline 19 & Jovita & VI.C & Menghina teman, melawan terhadap guru \\
\hline 20 & Cut Nafa & VI.D & Sering terlambat, tidak mengikuti kegiatan \\
\hline 21 & Adrian Disa & VI.D & Menendang temannya, teriak-teriak dikelas \\
\hline 22 & M.Iqbal Irvani & VI.D & Tidak mengerjakan tugas kelompok, berkata kotor \\
\hline 23 & Rio Dwi Putra & VI.D & Berkelahi sesama teman, bermain saat belajar \\
\hline 24 & Aqila Nugraha & V.B & Sering tidak mengerjakan PR, Bercanda saat belajar \\
\hline 25 & A. Bayu Saputra & V.B & Mencontek, bermain saat belajar \\
\hline 26 & M.Kholifah R & V.B & Sering terlambat, sering tidak membuat PR \\
\hline 27 & M.Rafi Eka P & V.B & Tidak ikut mengerjakan tugas kelompok \\
\hline 28 & M.Rafli Radican & V.B & Melawan pada guru, mencontek \\
\hline 29 & Rido Kurniawan & V.B & Menjawab perkataan guru, sering terlambat \\
\hline 30 & M.Abdhul W. & V.B & Merusak tanaman, malas membuat PR \\
\hline 31 & Maulidta Naflah & V.C & Malas, malas membuat tugas \\
\hline 32 & Al-Shifa Hatta & V.D & $\begin{array}{l}\text { Tidak terima bila dihukum, sering mengancam } \\
\text { temannya }\end{array}$ \\
\hline 33 & Farhan Tegar & V.D & Berkata kotor, mencaci, bermain saat belajar \\
\hline 34 & M.Gilang Fajrin & V.D & $\begin{array}{l}\text { Lalai terhadap tugas, Tidak memperhatikan } \\
\text { pelajaran }\end{array}$ \\
\hline 35 & Sehan Hamid & V.D & $\begin{array}{l}\text { Sering melawan guru, mengancam temannya jika } \\
\text { ditegur berbuat salah }\end{array}$ \\
\hline 36 & Rifka Dwi L & V.D & Mencaci temannya, berkata kotor \\
\hline 37 & Popy Devina & V.D & $\begin{array}{l}\text { Malas buat PR, Ribut dalam kelas, bila ditegur } \\
\text { menjawab }\end{array}$ \\
\hline 38 & Novi Wulandari & V.D & Sering terlambat, lalai terhadap tugas rumah \\
\hline 39 & A.Dino Utomo & V.D & jahil terhadap temannya \\
\hline 40 & Monica Adrean & V.D & Tidak piket kelas, bermain saat belajar \\
\hline
\end{tabular}

Sumber: Buku Catatan guru wali kelas terhadap pembelajaran karakter bangsa SD Negeri 2 Palapa

\section{METODE}

Penelitian ini merupakan penelitian Evaluatif, karena penelitian ini hanya untuk mengetahui implimentasi Kebijakan Pendidikan nasional Dalam Membentuk Karakter 
akhlak mulia Siswa di SD Negeri 2 Palapa Kecamatan Tanjung Karang Pusat Kota Bandar Lampung. Dalam penelitian evaluatif ini penulis menggunakan evaluasi program improvement, yaitu memberikan informasi bagaimana program berfungsi dan bekerja/berjalan? Apakah sesuai dengan pencapaian tujuan, adakah halhal atau masalah yang tak terduga (Tayibnapis, 2000: 15).

Penelitian ini bersifat kualitatif, karena penelitian ini mengungkap dan mengetahui keberhasilan kegiatan atau kegagalan dan mengetahui penyebabnya, dimungkinkan penyempurnaan kinerja program di masa mendatang dan menghindari kesalahan yang telah dibuat pada masa lalu.

\section{HASIL DAN PEMBAHASAN}

\section{Rancangan Pembinaan Pendidikan Akhlak Mulia Siswa Melalui Kegiatan Ekstrakurikuler \\ Visi Dan Misi Kegiatan}

Sesuai dengan amanat undangundang sistem pendidikan nasional No. 20 tahun 2003 bahwa kegiatan ektrakurikuler merupakan bagian dari bentuk layanan pendidikan untuk menunjang pendidikan sepanjang hayat. Pendidikan yang visioner, memiliki misi yang jelas, menghasilkan output yang bermutu. Berdasarkan latar belakang di atas maka program pembinaan pendidikan akhlak mulia yang dilaksanakan SD Negeri 2 Palapa Kecamatan Tanjung Karang Pusat Kota Bandar Lampung mempunyai visi dan misi yaitu, "Menciptakan siswa yang berprestasi berdasarkan iman, taqwa dan berakhlak mulia, serta disiplin dalam penerapan pola hidup bermoral (santun, bersih, dan sehat)".
Untuk mencapai visi tersebut maka misi SD Negeri 2 Palapa Kecamatan Tanjung Karang Pusat Kota Bandar Lampung adalah melengkapi sarana dan prasarana sekolah untuk menunjang terselenggaranya pendidikan, meningkatkan profesionalitas guru, menciptakan lingkungan sekolah yang tertib bersih dan nyaman, menyelenggarakan pembelajaran dengan menerapkan disiplin waktu, menyelenggarakan bimbingan kerohanian, menjalin kerjasama dengan masyarakat agar dapat meningkatkan kepeduliannya terhadap pendidikan.

Selain itu juga, SD Negeri 2 Palapa mempunyai program kerja kepala sekolah sebagai acuan dalam pelaksanaan program pembinaan pendidikan akhlak mulia. Adapun program kerja tersebut adalah: (a) Menciptakan rasa kekeluargaan di lingkungan sekolah; (b) Meningkatkan kerjasama dengan orang tua murid; (c) Meningkatkan mutu pendidikan; (d) Melengkapi sarana dan prasarana pendidikan; (e) Efektifitas dan efesiensi penggunaan sekolah; (f) Meningkatkan prestasi anak didik melalui akademik dan non akademik; (g) Meningkatkan profesionalisme guru dan tenaga kependidikan; (h) Mewujudkan peserta didik yang handal, mandiri, berprestasi, santun serta berakhlak mulia; (i) Meningkatkan mutu Iptek disekolah; dan (j) Meningkatkan mutu berdasarkan Pakem yang sepenuhnya didukungnya peran serta mesyarakat.

\section{Tujuan Kegiatan}

Tujuan dari penggunaan dana bantuan sosial adalah untuk peningkatan pendidikan akhlak mulia siswa melalui kegiatan ekstrakurikuler yang bertujuan untuk menciptakan siswa-siswi yang memiliki akhlak mulia 
sehingga dapat mendukung misi pembangunan nasional berupa pembangunan karakter bangsa sehingga dapat mewujudkan visi pembangunan nasional. Dalam pelaksanaanya kegiatan yang dilakukan SD Negeri 2 Palapa dengan mengadakan kegiatan Pramuka, Penyuluhan narkoba, perlombaan, Field trip, Kerja bakti dilingkungan sekolah, memperingati hari-hari besar islam, dan pengadaan alat-alat kebersihan.

\section{Program Dan Strategis Pelaksanaan}

Program dan kegiatan yang dilaksanakan oleh SD Negeri 2 Palapa Kecamatan Tanjung Karang Pusat Kota Bandar Lampung dengan menggunakan dana bantuan sosial kegiatan pembinaan pendidikan akhlak mulia adalah mengadakan kegiatan ekstrakurikuler guna meningkatkan kualitas akhlak mulia dan pribadi yang luhur pada keluarga besar SD Negeri 2 Palapa.

Pelaksanaan program kegiatan pembinaan pendidikan akhlak mulia yang dilakukan sekolah melalui kegiatan ekstrakurikuler keagamaan dan kepanduan yang berguna untuk meningkatkan akhalak dan pribadi yang luhur bagi keluarga besar SD Negeri 2 Palapa, umumnya dan siswa khususnya.

Program yang dapat dilaksanakan di sekolah SD Negeri 2 Palapa untuk meningkatkan akhlak dan pribadi yang luhur adalah kegiatan kerohanian yang meliputi doa dan zikir serta ceramah keagamaan, memperingati tahun baru islam $1432 \mathrm{H}$, lomba bercerita dan mengarang ketauladanan Nabi. Kegiatan sosialisasi yang meliputi pemahaman tentang narkoba bagi diri sendiri dan keluarga. Kegiatan kepanduan meliputi kunjungan siswa ke polresta Bandar Lampung dan kegiatan pelatihan pramuka. Kegiatan kesehatan jasmani meliputi kerja bakti di lingkungan sekolah, melengkapi alat kebersihan sekolah dan melakukan kegiatan senam pagi.

Program dan kegiatan yang direncanakan di SD Negeri 2 Palapa Kecamatan Tanjung Karang Pusat Kota Bandar Lampung adalah sebagai berikut:

Tabel 2

Rencana Program Kegiatan Ekstrakurikuler

\begin{tabular}{|c|c|c|c|}
\hline No & $\begin{array}{l}\text { Program } \\
\text { Ekstrakurikuler }\end{array}$ & Kegiatan & Akhlak Mulia \\
\hline \multirow[t]{2}{*}{1} & $\begin{array}{l}\text { Sosialisasi Bahaya } \\
\text { Narkoba. } \\
\text { Pemahaman narkoba }\end{array}$ & $\begin{array}{l}\text { Pemahaman tentang } \\
\text { narkoba (jenis dan bahaya } \\
\text { narkoba) }\end{array}$ & \multirow[t]{2}{*}{$\begin{array}{l}\text { Mencegah dan menghindar } \\
\text { bahaya narkoba. }\end{array}$} \\
\hline & $\begin{array}{l}\text { bagi diri sendiri dan } \\
\text { keluarga }\end{array}$ & $\begin{array}{l}\text { Menanamkan pemahaman } \\
\text { bahaya narkoba bagi diri } \\
\text { sendidri dan keluarga. }\end{array}$ & \\
\hline \multirow[t]{2}{*}{2} & $\begin{array}{l}\text { Kepanduan. } \\
\text { Melakukan kunjungan } \\
\text { dan kegiatan sosial di } \\
\text { tempat umum serta }\end{array}$ & $\begin{array}{l}\text { Melakukan kunjungan dan } \\
\text { kegiatan sosial di tempat } \\
\text { umum. }\end{array}$ & \multirow{2}{*}{$\begin{array}{l}\text { Bertujuan untuk } \\
\text { menanamkan sifat disiplin, } \\
\text { percaya diri, pantang } \\
\text { menyerah, mandiri dan } \\
\text { kerjasama antar siswa. }\end{array}$} \\
\hline & $\begin{array}{l}\text { melakukan pelatihan } \\
\text { kepanduan bagi siswa }\end{array}$ & $\begin{array}{l}\text { Pelaksanaan pelatihan } \\
\text { pramuka }\end{array}$ & \\
\hline
\end{tabular}




\begin{tabular}{|c|c|c|c|}
\hline \multirow[t]{4}{*}{3} & \multirow{4}{*}{$\begin{array}{l}\text { Kesehatan Jasmani. } \\
\text { Melakukan kerja bakti, } \\
\text { melengkapi alat } \\
\text { kebersihan sekolah dan } \\
\text { senam pagi setiap } \\
\text { jum'at }\end{array}$} & $\begin{array}{l}\text { Kerja bakti lingkungan } \\
\text { sekolah }\end{array}$ & \multirow{4}{*}{$\begin{array}{l}\text { Meningkatkan disiplin, } \\
\text { tanggung jawab dan hemat } \\
\text { bagi siswa-siswi dan } \\
\text { seluruh peserta didik }\end{array}$} \\
\hline & & Membeli perlengkapan & \\
\hline & & kebersihan & \\
\hline & & $\begin{array}{l}\text { Melakukan senam pagi } \\
\text { setiap hari jum'at }\end{array}$ & \\
\hline \multirow[t]{4}{*}{4} & \multirow[t]{4}{*}{$\begin{array}{l}\text { Rohani Islam. } \\
\text { Memperingati tahun } \\
\text { baru islam, lomba } \\
\text { mengarang, dan } \\
\text { bercerita ketauladanan }\end{array}$} & $\begin{array}{l}\text { Doa dan zikir serta } \\
\text { ceramah agama } \\
\text { memperingati tahun baru } \\
\text { islam }\end{array}$ & \multirow[t]{4}{*}{$\begin{array}{l}\text { Menungkatkan iman dan } \\
\text { taqwa seluruh peserta didik }\end{array}$} \\
\hline & & $\begin{array}{l}\text { Lomba ketauladanan Nabi } \\
\text { untuk kelas VI }\end{array}$ & \\
\hline & & Lomba kaligrafi & \\
\hline & & $\begin{array}{l}\text { Lomba menulis } \\
\text { ketauladanan Nabi }\end{array}$ & \\
\hline
\end{tabular}

Dokumentasi : SD Negeri 2 Palapa Tahun 2012

Keterangan participant (Peserta perempuan. Namun yang mengikuti Didik)

Jumlah peserta didik SD Negeri 2

Palapa Kecamatan Tanjung Karang

Pusat Kota Bandar Lampung berjumlah

1126 terdiri dari 546 laki-laki dan 580 program pembinaan pendidikan akhlak mulia berjumlah 345 orang siswa, terdiri dari siswa kelas 5 (lima) dan 6 (enam) dengan rincian sebagai berikut:

Tabel 3

Daftar jumlah peserta yang dijadikan fokus program kegiatan pendidikan akhlak mulia SD Negeri 2 Palapa Kecamatan Tanjung Karang Pusat Kota Bandar Lampung

\begin{tabular}{ccccc}
\hline \multirow{2}{*}{ No } & \multirow{2}{*}{ Kelas } & \multicolumn{2}{c}{ Jumlah Siswa } & \multirow{2}{*}{ Jumlah } \\
\cline { 3 - 4 } & & Laki-laki & Perempuan & \\
\hline 1 & V. A & 31 & 17 & 48 \\
\hline 2 & V. B & 28 & 17 & 45 \\
\hline 3 & V. C & 25 & 19 & 44 \\
\hline 4 & V. D & 25 & 19 & 44 \\
\hline 5 & VI. A & 12 & 29 & 41 \\
\hline 6 & VI. B & 22 & 19 & 41 \\
\hline 7 & VI. C & 19 & 19 & 38 \\
\hline 8 & VI. D & 24 & 20 & 44 \\
\hline & & Jumlah & & $\mathbf{3 4 5}$
\end{tabular}

Sumber : Dokumentasi Laporan Kegiatan Pembinaan Pendidikan Akhlak Mulia SD Negeri 2 Palapa 
Implementasi Pembinaan Pendidikan Akhlak Mulia Siswa Melalui Kegiatan Ekstrakurikuler

Sesuai dengan undang-undang nomor 20 tahun 2003 tentang sistem pendidikan nasional, keputusan menteri pendidikan nasional nomor 14/U/2005 tahun 2005 tentang organisasi dan tata kerja Ditjen Mandikdasmen, Peraturan menteri pendidikan nasional nomor 39 tahun 2008 tentang pembinaan siswa, keputusan menteri pendidikan nasional RI nomor 1999/A.A3/KU/2010 tanggal 12 Januari 2010 tentang pengangkatan pejabat perbendaharaan/pengelolaan keuangan pada sekretariat Ditjen Mandikdasmen tahun anggaran 2010, DIPA Sekretariat Ditjen Mandikdasmen, kegiatan pembinaan pendidikan agama dan akhlak mulia nomor 0033/023.03.1/-/2010 tanggal 21 Desember 2009 (Kemendiknas, 2010: 35).

Pada saat ini konsep pendidikan telah tumbuh dan berkembang demikian pesat, dengan bentuk isi dan penyelenggaraan program pendidikan beraneka ragam dari tingkat yang sederhana sampai tingkat yang komplek. Dalam hal ini pemerintah berupaya menyelenggarakan pendidikan yang bersifat keagamaan maupun yang bersifat umum, begitu juga dengan SD Negeri 2 Palapa tidak tinggal diam dalam kepedulian terhadap pembinaan pendidikan karakter akhlak mulia di sekolah dan diluar sekolah melalui kegiatan ekstrakurikuler dengan bermuatan pendidikan nilai-nilai karakter siswa.

Uraian diatas menjelaskan pendidikan dalam wujud cita-citanya dalam visi dan misinya, untuk mencapai program pembinaan pendidikan akhlak mulia dibutuhkan tambahan program kegiatan ekstrakurikuler sebagai tambahan ilmu pengetahuan bagi siswa diluar jam pelajaran disekolah. Pelaksanaan pendidikan karakter akhlak mulia di tingkat sekolah dasar masih terbatas pada kegiatan sederhana, mudah dipahami, tidak membutuhkan waktu yang melelahkan, serta disesuaikan dengan ketersediaan fasilitas, nara sumber, dan kondisi sekolah.

Dari keseluruhan program yang direncanakan oleh kementrian pendidikan nasional melalui kementrian pendidikan nasional direktorat jendral menejemen pendidikan dasar dan menengah dan petunjuk teknis (JUKNIS) bantuan sosial kegiatan pembinaan akhlak mulia tahun 2010, SD Negeri 2 Palapa Kecamatan Tanjung Karang Pusat Kota Bandar Lampung telah melaksanakan program kegiatan pembinaan pendidikan akhlak mulia siswa melalui kegiatan ekstrakurikuler berupa sosialisasi bahaya narkoba, kepanduan, kesehatan jasmani, kegiatan pramuka, dan rohani islam dan lain sebagainya. Lebih jelasnya lihat tabel berikut :

Tabel 4

Pelaksanaan Kegiatan Ekstrakurikuler

\begin{tabular}{lllll}
\hline No & $\begin{array}{c}\text { Program } \\
\text { Ekstrakurikuler }\end{array}$ & Jenis Kegiatan & \multicolumn{1}{c}{ Uraian } & Nilai Akhlak Mulia \\
\hline 1 & Sosialisasi Bahaya & Penerangan & - Pemahaman & Mencegah dan \\
& Narkoba & Bahaya Narkoba & $\begin{array}{l}\text { tentang narkoba } \\
\text { (jenis dan bahaya }\end{array}$ & $\begin{array}{l}\text { menghindari } \\
\text { bahaya narkoba }\end{array}$ \\
& & & narkoba) \\
& & & Menanamkan \\
& & & \\
& & & pemahaman \\
\hline
\end{tabular}




\begin{tabular}{|c|c|c|c|c|}
\hline & & & $\begin{array}{l}\text { bahaya narkoba } \\
\text { bagi diri sendidri } \\
\text { dan keluarga. }\end{array}$ & \\
\hline 2 & $\begin{array}{l}\text { Kepanduan } \\
\text { Melakukan } \\
\text { kunjungan dan } \\
\text { kegiatan sosial } \\
\text { ditempat umum } \\
\text { serta melakukan } \\
\text { pelatatihan } \\
\text { kepanduan siswa }\end{array}$ & $\begin{array}{l}\text { Outbond bagi } \\
\text { siswa kelas IV }\end{array}$ & $\begin{array}{l}\text { - Kunjungan siswa } \\
\text { ke Poltabes } \\
\text { Bandar Lampung } \\
\text { - Pelatihan } \\
\text { Pramuka }\end{array}$ & $\begin{array}{l}\text { Disiplin, percaya } \\
\text { diri, pentang } \\
\text { menyerah, mandiri } \\
\text { dan kerjasama } \\
\text { antar siswa }\end{array}$ \\
\hline 3 & $\begin{array}{l}\text { Kesehatan } \\
\text { Jasmani } \\
\text { Melakukan kerja } \\
\text { bakti, melengkapi } \\
\text { alat kebersihan } \\
\text { sekolah, dan senam } \\
\text { pagi setiap jum'at }\end{array}$ & $\begin{array}{l}\text { Pelaksanaan } \\
\text { Kebersihan dan } \\
\text { Kesehatan siswa }\end{array}$ & $\begin{array}{l}\text { - Kerja Bakti } \\
\text { membersihkan } \\
\text { Lingkungan } \\
\text { Sekolah } \\
\text { - Membeli } \\
\text { perlengkapan } \\
\text { kebersihan } \\
\text { - Senam pagi setiap } \\
\text { jum'at } \\
\text { - Olah raga } \\
\end{array}$ & $\begin{array}{l}\text { Meningkatkan } \\
\text { disiplin, Tanggung } \\
\text { jawab, dan hemat }\end{array}$ \\
\hline 4 & Rohani Islam & $\begin{array}{l}\text { 1. Memperingati } \\
\text { tahun baru } \\
\text { islam } \\
\text { 2. Lomba } \\
\text { bercerita dan } \\
\text { mengarang } \\
\text { ketauladanan } \\
\text { Nabi }\end{array}$ & $\begin{array}{l}\text { - Doa dan zikir } \\
\text { serta ceramah } \\
\text { agama } \\
\text { - Lomba bercerita } \\
\text { - Lomba melukis } \\
\text { - Lomba kaligrafi }\end{array}$ & $\begin{array}{l}\text { Kewarganegaraan, } \\
\text { berpikir positif, } \\
\text { cinta damai, Jujur, } \\
\text { Percaya diri, kerja } \\
\text { keras, pantang } \\
\text { menyerah, } \\
\text { bertanggung jawab, } \\
\text { kerjasama, dan } \\
\text { kreatif }\end{array}$ \\
\hline 5 & Pramuka & $\begin{array}{l}\text { Kegiatan } \\
\text { Pramuka }\end{array}$ & $\begin{array}{l}\text { Kegiatan yang } \\
\text { mengarah kepada } \\
\text { pengalaman dasa } \\
\text { darma pramuka } \\
\text { dan try satya } \\
\text { difokuskan pada } \\
\text { darma no.3 patriot } \\
\text { yang sopan dan } \\
\text { kesatria dituangkan } \\
\text { dalam program } \\
\text { bina diri, bina } \\
\text { satuan, dan bina } \\
\text { masyarakat }\end{array}$ & $\begin{array}{l}\text { Mengembangkan } \\
\text { sikap: Disiplin, } \\
\text { percaya diri, } \\
\text { pantang menyerah, } \\
\text { hemat, adil, } \\
\text { berpikir fositif, } \\
\text { mandiri, } \\
\text { pengendalian } \\
\text { emosi, } \\
\text { tanggungjawab, } \\
\text { kreatif, kerjasama, } \\
\text { kerja keras }\end{array}$ \\
\hline
\end{tabular}

Sumber : Data Dokumen SD Negeri 2 Palapa Kec. Tanjung Karang Pusat

Sesuai dengan judul penelitian ini mulia siswa melalui kegiatan adalah implementasi program ekstrakurikuler di SD Negeri 2 Palapa pembinaan pendidikan karakter akhlak Tanjung Karang Pusat Kota Bandar 
Lampung, bahwa aktivitas yang dilakukan dalam kegiatan ekstrakurikuler merupakan aspek yang saling mendukung dengan pembelajaran akhlak mulia peserta didik yang diterima dikelas, akan mendapatkan tambahan pembelajaran secara praktek dalam kegiatan ekstrakurikuler.

Karena dalam kegiatan ekstrakurikuler merupakan bagian dari pembinaan karakter akhlak mulia kesiswaan di sekolah. Pembinaan kesiswaan itu berupa: Pembinaan keimanan dan ketaqwaan kepada tuhan yang maha Esa, pembinaan budi pekerti luhur atau akhlak mulia, pembinaan keperibadian unggul, wawasan kebangsaan dan bela Negara, pembinaan prestasi akademik, seni dan olahraga sesuai dengan bakat dan minat, pembinaan demokrasi, hak asasi manusia, pendidikan politik, lingkungan hidup, kepekaan, dan toleransi, pembinaan kreativitas, keterampilan, dan kewirausahaan, pembinaan kulitas jasmani, kesehatan, dan gizi, pembinaan sasra dan budaya, pembinaan teknologi informasi dan komunikasi (Aqib \& Sujak, 2011: 71-73).

Untuk

menjabarkan ini

implementasi program pembinaan pendidikan karakter akhlak mulia Di SD Negeri 2 Palapa Tanjung Karang Pusat Kota Bandar Lampung melaksanakan program kegiatan pembinaan pendidikan karakter akhlak mulia yang telah dilakukan terfokus pada kegiatankegiatan berikut ini : (1) Sosialisasi bahaya narkoba; (2) Kepanduan; (3) Kesehatan jasmani; dan (4) Rohani Islami.

\section{Sosialisasi Bahaya Narkoba}

Pencegahan penyalahgunaan narkoba (narkotika, psikotropika, dan bahan-bahan adektif lainnya) di sekolah pada dasarnya upaya sadar penciptaan sistem lingkungan pendidikan yang kondusif dalam bentuk pembelajaran, pembimbingan, dan atau pelatihan yang membekali pemahaman, pengalaman, keterampilan, dan kontrol diri pada setiap peserta didik untuk mencapai mutu kehidupan yang sehat. Dengan kata lain, pendidikan pencegahan penyalahgunaan narkoba disekolah adalah upaya yang sistematik dalam rangka menjadikan sekolah sebagai lingkungan pendidikan yang sehat guna peningkatan mutu sumber daya manusia.

Dalam mengimplementasikan program sosialisasi bahaya narkoba, akan memberikan kontribusi pada pembelajaran pendidikan Karakter tentang pemahaman tentang narkoba, jenis dan bahaya narkoba, menanamkan pemahaman narkoba bagi diri sendiri dan keluarga untuk mencegah serta menghindari bahaya narkoba yang dilakukan oleh SD Negeri 2 Palapa Tanjung Karang Pusat Kota Bandar Lampung. Cara pelaksanaan dilaksanakan dengan mengadakan seminar tentang narkoba dan bahaya narkoba bagi diri sendiri dan keluarga, memberikan buku panduan tentang sosialisasi narkoba dan bahayanya, serta mengadakan lomba menggambar tentang bahaya jenis dan bahaya narkoba.

Secara umum tujuan pendidikan pencegahan penyalahgunaan narkoba adalah untuk mengembangkan kemampuan warga sekolah dalam berperilaku sehat dan memfasilitasi penyaluran energi psikofisik para peserta didik secara terncana dan terpadu dalam keseluruhan program pendidikan di sekolah. Secara khusus, pendidikan penyalahgunaan narkoba disekolah ditujukan agar para peserta didik menguasai:(a) Pemahaman 
tentang penyalahgunaan narkoba; (b) ikap yang positif dalam mengembangkan pola perilaku dan hidup yang sehat; dan (c) Keterampilan mengelola dan mengontrol diri yang konstruktif dalam menghindari tayangan penyalahgunaan narkoba (Aqib \& Sujak, 2011: 88-89).

Farid Wijaya (guru SD Negeri 2 Palapa Bandar lampung) menerangkan bahwa kegiatan ini bertujuan sebagai pengetahuan bagi peserta didik, khususnya sekolah tentang bahaya narkoba bagi dirinya dan sebagai sebuah refrensi sehingga anak-anak bisa mengerti tentang jenis-jenis narkotika. Kegiatan ini dilakukan sebanyak dua kali yaitu tanggal 6 November dan 13 November 2011 dengan mengundang tutor dari Kapoltabes Kota Bandar Lampung serta dibantu oleh tutor dari SD Negeri 2 Palapa sendiri.
Kegiatan ini di ikuti oleh siswasiswi kelas VI (enam) yang berjumlah 164 siswa, kegiatan ini wajib di ikuti oleh siswa kelas VI (enam) yang dilaksanakan sebanyak dua kali, untuk memperdalam materi tentang narkoba siswa diberikan buku panduan tentang pengetahuan jenis narkoba dan bahaya terhadap dirinya sendiri dan keluarga. Setelah melaksanakan kegiatan sosialisasi pihak sekolah mengadakan perlombaan menggambar tentang jenis narkotika atau yang berkaitan dengan bahaya narkoba. Dalam pelaksanaanya kegiatan perlombaan ini diikuti oleh perwakilan tiap kelas yaitu kelas IV, V dan VI, masing-masing kelas mengutus 4 orang peserta yang terdiri dari laki-laki dan perempuan, dalam perlombaan ini pemenangnya akan mendapatkan hadiah dan piagam penghargaan. Adapun pemenang perlombaan ini adalah sebagaimana tabel berikut:

Tabel 5

Pemenang perlombaan menggambar tentang bahaya Narkoba

\begin{tabular}{llcc}
\hline No & \multicolumn{1}{c}{ Nama Pemenang } & Utusan Kelas & Keterangan \\
\hline 1 & Cahya Zila Asriani & V.D & Juara Satu \\
2 & Sigit Waluyo & IV.A & Juara Dua \\
3 & Regita Amanda & V.B & Juara Tiga \\
\hline
\end{tabular}

Sumber : Dokumentasi SD Negeri 2 Palapa Tanjung Karang Pusat

Dengan demikian dapat dipahami bahwa dengan adanya kegiatan sosialisasi dan perlombaan yang telah dilaksanakan oleh sekolah SD Negeri 2 Palapa diatas siswa-siswi dapat memahami jenis narkotika dan bahayanya terhadap diri sendiri dan keluarga. Nilai-nilai pendidikan karakter akhlak mulia yang terkandung dalam kegiatan sosialisasi dan perlombaan tersebut adalah mencintai diri sendiri, keluarga, toleransi, kewarganegaraan dan cinta terhadap sesama teman (Kemendiknas, 2010: 35).

\section{Kepanduan}

Dalam mengimplementasikan program pembinaan ini berupa kegiatan yang meliputi kunjungan siswa ke Poltabes Bandar Lampung, dan pelatihan kegiatan pramuka.

Kunjungan Ke-Poltabes Bandar Lampung Dengan melakukan kunjungan siswa dapat mengalami langsung kejadian dilapangan, sehingga siswa dapat merasakan bahwa apa yang 
dipelajari di dalam kelas dapat diaplikasikan dalam kehidupan seharihari. Dalam pelaksanaanya, Yudo Martopo (guru penjaskes SD Negeri 2 Palapa) mengemukakan bahwa program kunjungan (field trip) ke Poltabes Bandar Lampung dapat terlaksana karena adanya kerja sama dengan poltabes. Pada kegiatan kunjungan tersebut, dilaksanakan kegiatan kebersihan bersama disekitar poltabes, praktek pelatihan baris berbaris (PBB), dan kegiatan polisi cilik Lampung (PCL).

Tarmizi (guru sekaligus ketua Program Pembinaan Pendidikan Akhlak Mulia SD Negeri 2 Palapa Bandar Lampung) menambahkan bahwa melalui kegiatan ini diharapkan dapat menanamkan nilai-nilai akhlak mulia kepada siswa-siswi berupa nilai santun, percaya diri, berpikir positif, mandiri, toleransi, tanggung jawab, kasih sayang, dan kerjasama. Dalam pelaksanaan kegiatan field trip ini siswa-siswi mempunyai pengalaman yang sangat berharga dan membiasakan peserta didik berperilaku dengan perilaku bersih, kerjasama, kasih sayang, dan lain sebagainya. Sebagaimana hasil wawancara dengan salah satu siswa kelas V SD Negeri 2 Palapa (M. Gilang Fajrin) bahwa dia merasa kegiatan kunjungan kepoltabes dengan mengadakan bersih-bersih, pelatihan baris berbaris dan polisi cilik Lampung dapat membimbing dirinya menjadi seorang mandiri, berperilaku hidup bersih, kerjasama, disiplin, kasih sayang, dan kerja keras.

\section{Pelatihan Kegiatan Pramuka}

Pelaksanaan pelatihan kegiatan pramuka dapat melatih siswa-siswi menjadi pemimpin, kemandirian, kerjasama, dan sikap pantang menyerah dalam kesulitan yang dihadapi, selain itu juga siswa juga diajarkan untuk memiliki sikap rendah hati dan sederhana. Dalam pelaksanaanya kegiatan ini dilakukan setiap hari Sabtu dan pembelian alat-alat pramuka, kegiatan pelatihan pramuka ini diikuti oleh kelas IV, V dan VI SD Negeri 2 Palapa secara bergantian. Dengan rincian siswa-siswinya sebagai berikut :

Tabel 6

Daftar jumlah Peserta Didik di SD Negeri 2 Palapa

\begin{tabular}{ccccc}
\hline \multirow{2}{*}{ No } & \multirow{2}{*}{ Kelas } & \multicolumn{2}{c}{ Jumlah } & \multirow{2}{*}{ Jumlah } \\
\cline { 3 - 4 } 1 & I & 108 & Perempuan & 215 \\
2 & II & 87 & 107 & 189 \\
3 & III & 84 & 102 & 178 \\
4 & IV & 98 & 94 & 193 \\
5 & V & 77 & 95 & 172 \\
6 & VI & 92 & 95 & 179 \\
\hline & & Jumlah Keseluruhan & $\mathbf{1 1 2 6}$
\end{tabular}

\section{Sumber : Dokumentasi SD Negeri 2 Palapa Tahun 2011/2012}

Dari tabel diatas jumlah peserta didik kelas IV, V, dan VI berjumlah 544 siswa, namun yang aktif mengukuti pelatihan pramuka hanya berjumlah 50 orang peserta dengan rincian sebagai berikut 
Tabel 7

Daftar jumlah Peserta yang aktif mengikuti pelatihan pramuka di SD Negeri 2 Palapa

\begin{tabular}{ccccc}
\hline No & Kelas & \multicolumn{2}{c}{ Jumlah } & Jumlah \\
\cline { 3 - 4 } & & Laki-laki & Perempuan & \\
\hline 1 & IV & 8 & 5 & 13 \\
2 & V & 9 & 7 & 16 \\
3 & VI & 12 & 9 & 21 \\
\hline \multicolumn{3}{c}{ Jumlah Keseluruhan } & $\mathbf{5 0}$
\end{tabular}

Sumber : Dokumentasi SD Negeri 2 Palapa Tahun 2011/2012

Kegiatan pramuka bertujuan untuk menciptakan peserta didik cerdas, trampil, dan disiplin serta cakap dalam tata laksana kepramukaan pada pola kehidupan yang taat dan berakhlak mulia. Karena dalam dalam gerakan pramuka sebagai landasan pijak dalam beraktivitas adalah dasa darma sebagaimana yang termaktubp darma ketiga yakni patriot yang sopan dan kesatria dan darma yang kesepuluh yakni suci dalam pikiran, perkataan dan perbuatan (Napitupulu, 2010: 6). Guna untuk menunjang keberhasilan tersebut perlu diselenggarakan kegiatan latihan yang terdiri dari pembinaan yang tersusun dalam program kegiatan latihan rutin yang diselenggarakan setiap hari Sabtu. Maka berikut agenda latihan pramuka yang diadakan SD Negeri 2 Palapa Tanjung Karang Pusat:

Tabel 8

Bidang Latihan Peserta Didik

\begin{tabular}{lll}
\hline Materi Pokok & Materi Latihan & Semester \\
\hline 1. Sejarah Pramuka & - Salam Pramuka & \\
2. Janji Kode Pramuka & - Struktur Organisasi Pramuka & \\
& - Tri satya & \\
3. PBB & - Bentuk barisan & \\
& - Kreasi baris-berbaris \\
& - Macam-macam intruksi baris-berbaris \\
4. Tali temali & - Macam-macam tali temali \\
& - Pioneering \\
& - Cara mendirikan tenda \\
5. Sandi & - Morse \\
& - Samapur \\
& - Macam-macam sandi \\
& - Pedoman kompas & \\
\hline
\end{tabular}

Sumber : Dokumen Gugus Depan SD Negeri 2 Palapa Tahun 2011/2012

Dalam bidang yang lain, M. Eka Sanjayoy (guru SD Negeri 2 Palapa) menerangkan bahwa untuk mendukung kegiatan latihan pramuka gugus depan SD Negeri 2 Palapa, maka sekolah mengupayakan kelengkapan sarana dan prasarana pramuka dengan membeli peralatan yang mendukung kegiatan tersebut seperti komputer, tenda pembina, tenda anggota penggalang, perlengkapan dapur dan lain sebagainya. 
Pada hari Sabtu pagi siswa berkumpul dengan barang-barang yang dibawa dari rumah, secara bersamasama mendirikan tenda di lapangan Bukit Kemiling Permai mengikuti permainan dan kegiatan yang sifatnya simulasi dan bermain peran. Membuat proyek bersama yang berkaitan dengan kebersihan, melestarikan budaya Indonesia dengan cara merancang pentas seni, masak bersama, api unggun, do'a malam dan renungan, serta upacara pagi.

$\begin{array}{rccr}\text { Dari } & \text { hasil } & \text { observasi } & \text { dan } \\ \text { penjelasan diatas } & \text { maka dapat }\end{array}$ disimpulkan bahwa, kegiatan pelatihan pramuka ini menanamkan nilai-nilai pembelajaran dan pendidikan yang bertujuan membentuk karakter peserta didik yang disiplin, tanggung jawab, kerja keras, jujur, santun, kerjasama dan kerja keras. Pernyataan ini dikuatkan oleh salah satu Penanggung jawab kegiatan kepramukaan SD Negeri 2 Palapa (Arasiyah), beliau menyatakan bahwa kegiatan pramuka ini bertujuan untuk mendidik, melatih dan membiasakan peserta didik agar mempunyai keperibadian yang disiplin, kerjasama, kreatif, kerja keras, jujur, santun, rendah hati, ikhlas, tanggung jawab dan percaya diri.

\section{Pembinaan Kesehatan Jasmani}

Lingkungan, kebersihan dan kesehatan mengajak siswa untuk menghargai gaya hidup sehat dengan menjaga kebersihan diri sendiri, lingkungan dan kelas, selain itu juga mengajarkan anak untuk peduli dan peka terhadap lingkungan. Sekolah yang dilingkungannya secara fisik bebas dari hal-hal yang membahayakan kesehatan siswa dan warga sekolahnya mempunyai sikap dan perilaku hidup sehat. Ciri sekolah bersih dan sehat adalah: (1) Lingkungan sekolah yang bebas dari zat kimia yang berbahaya, seperti: debu, air keras, spritus, bensin, dan asam sulfat; (2) Lingkungan di dalam kelas baik dengan memperhatikan hal-hal sebagai berikut: Penerangan yang memadai,vintilasi yang memadai, kegiatan kebersihan dan perawtan kelas/sekolah berkelanjutan dan berkesinambungan seperti bebas polusi, bebas rokok, tersedianya air bersih; (3) Sekolah bebas dari makanan dan minuman yang dijual/dijajakan dikantin sekolah yang dianggap sehat padahal mengandung berbagai bahan dan zat kimia yang dapat merusak kesehatan siswa; dan (4) Adanya program, kegiatan, kebijakan dan aturan-aturan untuk menciptakan lingkungan sekolah bersih dan sehat (Aqib \& Sujak, 2011: 33-34).

Kesehatan jasmani bertujuan untuk membentuk karakter peserta didik agar sehat jasmani dan ruhani, dan menumbuhkan rasa sportivitas (Barnawi \& Arifin, 2012: 59). Dalam pelaksanaan kegiatan ini dilakukan dengan melakukan kerja bakti, melengkapi alat-alat kebersihan sekolah dan senam pagi setiap Jum'at, memasang stiker dengan bertulisan matikan air', 'matikan lampu', buang sampah pada tempatnya', dan menyediakan tempat sampah yang terpisah untuk sampah organik dan non organik, serta tempat sampah tersebut diletakan di dalam setiap kelas dan depan masing-masing kelas, serta melengkapi sarana dan prasarana kebersihan.

Dalam kesepatan lain penulis juga mengadakan wawancara kepada Syaima Eigipta (Siswa Kelas V SD Negeri 2 Palapa) untuk melengkapai pernyataan hasil observasi penulis sebagai berikut: "Setiap hari jum'at pagi kami melaksanakan senam pagi, bersih-bersih 
dilingkungan sekolah dan menabung". Demikian juga guru bahasa Inggris juga mengatakan bahwa "Setelah siswa-siswi mengikuti senam pagi siswa-siswi juga melakukan kerjabakti membersihkan lingkungan sekolah, dengan harapan siswa-siswi terbiasa berperilaku hidup sehat dan bersih serta disiplin."

Dari hasil observasi dan wawancara penulis di atas dapat disimpulkan bahwa dengan adanya kegiatan kesehatan jasmani di atas dapat meningkatkan disiplin peserta didik dan membiasakan siswa-siswi berperilaku hidup sehat dan bersih. Dengan program kegiatan kesehatan jasmani dapat menanamkan nilai-nilai karakter akhlak mulia siswa yang dapat bertanggung jawab, hemat, disiplin dan berperilaku hidup sehat dan bersih.

\section{Pembinaan Rohani Islam}

Peringatan hari-hari keagamaan dapat direalisasikan dalam bentuk kegiatan bersama-sama melakukan atau memperingati hari bersejarah, memperingati hari-hari besar Islam, Lomba keagamaan, doa bersama, dan renungan. Dalam pelaksanaanya SD Negeri 2 Palapa telah melakukan kegiatan yang berhubungan dengan rohani Islam seperti tabel berikut:

Tabel 9

Program Kegiatan Rohani Islam

\begin{tabular}{|c|c|c|c|}
\hline No & Program & Kegiatan & Uraian Kegiatan \\
\hline & & $\begin{array}{l}\text { - Memperingati Tahun } \\
\text { Baru Islam }\end{array}$ & $\begin{array}{l}\text { - Doa dan Zikir serta ceramah Agama } \\
\text { Tahun Baru Islam } 1433 \mathrm{H}\end{array}$ \\
\hline 1 & $\begin{array}{l}\text { Rohani } \\
\text { Islam }\end{array}$ & $\begin{array}{l}\text { - Lomba Bercerita dan } \\
\text { Mengarang } \\
\text { Ketauladanan Nabi }\end{array}$ & $\begin{array}{l}\text { - Lomba bercerita ketauladanan Nabi } \\
\text { tingkat kelas VI } \\
\text { - Lomba melukis kaligrafi }\end{array}$ \\
\hline
\end{tabular}

Sumber: Dokumentasi SD Negeri 2 Palapa Tanjung Karang Pusat Th. 2011/2012

Dari tabel diatas dapat dijelaskan bahwa, kegiatan rohani islam dilaksanakan dengan mengadakan kegiatan memperingati tahun baru islam dengan melaksanakan do'a dan zikir serta ceramah agama dan mengadakan perlombaan keteladanan Nabi dan kaligrafi. Semua kegiatan rohani islam tersebut bertujuan untuk meningkatkan iman dan taqwa seluruh peserta didik. Kegiatan rohani islam juga dapat dilaksanakan dengan bentuk kegiatan peringatan isra' mi'raj atau maulid Nabi untuk menanamkan nilai-nilai akhlak mulia berpikir positif, cinta damai dan kewarganegaraan (Kemendiknas, 2010).
Pelaksanaan program kegiatan bina rohani islam yang dilaksanakan dengan mengundang penceramah, dan dilaksanakan di lapangan sekolah,dan ruangan kelas. sebagaimana dengan hasil wawancara dengan guru agama SD Negeri 2 palapa menyatakan bahwa, “Kegiatan bina rohani berupa isra' mi'raj dan meperingati tahun baru islam yang dilaksnanakan disekolah SD Negeri 2 Palapa dilapangan dengan mengundang penceramah, sedang perlombaanperlombaan dilaksanakan di ruang kelas." Pada kesempatan yang lain penulis mengadakan wawancara dengan kepala sekolah yang menyatakan bahwa, "Kegiatan bina rohani ini bertujuan 
untuk meningkatkan iman dan taqwa siswa dan membiasakan siswa berperilaku, jujur, percaya diri, kerja keras, pantang menyerah, bertanggungjawab, kerjasama, kreatif, berpikir positif, dan cinta damai."

Dari penjelasan di atas dapat diambil sebuah benang merahnya bahwa kegiatan bina rohani yang diadakan oleh SD Negeri 2 Palapa dengan cara meperingati tahun baru islam seperti ceramah agama, zikir dan doa bersama, dan dengan cara mengadakan lomba bercerita keteladanan Nabi dan lomba kaligrafi. Adapun nilai-nilai yang terkandung dalam kegiatan bina rohani tersebut adalah menanamkan perilaku yang positif seperti perilaku siswa yang jujur, percaya diri, kreatif, kerja keras, bertanggungjawab, pantang menyerah, dan cinta damai.

Dalam pengimplimentasian program kegiatan pembinaan pendidikan karakter akhlak mulia yang dilaksnakan SD Negeri 2 Palapa dengan cara penerapan, pembiasaan, dan keteladanan. Terlihat bahwa akhlak mulia siswa ditujukan pada tingkahlaku keseharian disekolah, bertanggung jawab terhadap tugas-tugas yang diberikan guru dalam mengerjakan pekerjaan rumah (PR), siswa terlihat bergegas berbaris dengan rapi ketika bel telah dibunyikan, antosias dalam mengikuti perlombaan, membuang sampah pada tempatnya, siwa disiplin dalam mengikuti proses pembelajaran dikelas dan tidak terlambat dalam mengikuti pelajaran disekolah.

Berdasarkan pengamatan yang dilakukan peneliti, terhadap perilaku siswa SD Negeri 2 Palapa ditemukan adanya perilaku siswa yang sopan terhadap guru, teman, gotong royong membersihkan lingkungan sekolah, memberikan sumbangan kepada teman dan gurunya ketika mendapatkan musibah, ketika temannya melakukan pelanggaran memberi tahunya. Adapula siswa yang berperilaku tidak sopan terhadap guru, staf tata usaha, kurang peduli terhadap kebersihan, membuang sampah sembarangan, suka mengolokolok temannya, tidak membuat tugas rumah, sering bolos. Hal ini lebih jelas dapat dilihat dari tabel berikut:

Tabel 10

Prosentasi perilaku siswa yang bermasalah dan tidak bermasalah sebelum adanya program pembinaan pendidikan karakter akhlak mulia

\begin{tabular}{llcc}
\hline No & Uraian & Jumlah Siswa & Prosentasi \\
\hline 1 & Siswa yang bermasalah & 45 & $155 \%$ \\
2 & Siswa yang tidak bermasalah (berakhlak mulia) & 300 & $104 \%$ \\
\hline \multirow{2}{*}{ Jumlah seluruh siswa } & 345 & $100 \%$
\end{tabular}

Sumber: Buku Catatan Kasus SD Negeri 2 Palapa Tahun 2011/2012

Tabel 11

Prosentasi perilaku siswa yang bermasalah dan tidak bermasalah sesudah adanya program pembinaan pendidikan karakter akhlak mulia

\begin{tabular}{clcc}
\hline No & \multicolumn{1}{c}{ Uraian } & $\begin{array}{c}\text { Jumlah } \\
\text { Siswa }\end{array}$ & Prosentasi \\
\hline 1 & Siswa yang bermasalah & 10 & $34,5 \%$ \\
\hline 2 & Siswa yang tidak bermasalah (berakhlak mulia) & 335 & $116 \%$ \\
\hline
\end{tabular}




\begin{tabular}{ccc}
\hline Jumlah seluruh siswa & 345 & $100 \%$ \\
\hline
\end{tabular}

Sumber: Buku Catatan Kasus SD Negeri 2 Palapa Tahun 2011/2012

Kriteria siswa bermasalah adalah : Berbicara dan bertindak tidak sesuai tata krama, menyakiti temannya, merusak tanaman, pelit, tidak mengerjakan tugas rumah, berkelahi, ribut dalam kelas sambil naik meja, merendahkan dan menghina teman, mencontek, berbohong, membuang sampah sembarangan, boros, memilihmilih teman, merasa tidak mampu sebelum mencoba, tidak terima dihukum ketika berbuat kesalahan, pengaduan dari orang tua siswa maupun masyarakat.

Berdasarkan table diatas, terlihat bahwa siswa kelas V dan VI yang dijadikan fokus kegiatan pembinaan pendidikan akhlak mulia di SD Negeri 2 Palapa, terlihat bahwa siswa yang berakhlak buruk lebih kecil presentasinya ketimbang siswa yang berakhlak mulia. Menurut Bustami Arifin (kepala sekolah SD Negeri 2 Palapa Bandar Lampung) untuk memantau perkembangan perilaku akhlak mulia SD Negeri 2 Palapa apakah baik atau buruk, guru dan wali kelas diberikan buku pembinaan pelajaran karakter bangsa.

\section{Perkembangan Akhlak Mulia Siswa Setelah Pelaksanaan Program Pembinaan pendidikan akhlak mulia Akhlak siswa terhadap sesama teman}

Berdasarkan pengamatan yang dilakukan peneliti, ada beberapa siswa yang bersikap kurang baik terhadap sesama teman sebelum aktif adanya program pembinaan pendidikan karakter akhlak siswa masih ada yang suka mengganggu temannya yang mengakibatkan terjadinya keributan sesama temannya.
Menurut Yuli S.Hi (guru agama islam SD Negeri 2 Palapa Bandar Lampung), beberapa peserta didik masih sering berselisih. Hal ini disebabkan mereka sering mengganggu, saling mengolok-olok dan saling melempar sesama temannya ketika bermain di dalam kelas maupun diluar kelas, namun ketika siswa mengikuti program pembinaan akhlak mulia, siswa terlihat peningkatan akhlaknya.

Berdasarkan observasi penulis terdapat 8 orang siswa bermasalah , yang terdiri dari 2 orang yang sering berkelahi, 3 orang yang sering mengganggu temannya ketika proses belajar mengajar berlangsung, 1 orang yang sering mengambil barang temannya tampa izin, dan 2 orang siswa yang saling lempar kertas sesama temannya. Dari kedelapan orang ini ketika dalam kegiatan pembinaan akhlak mulia diberi bimbingan khusus dengan kegiatan pramuka dan rohani islam. Bimbingan ini diadakan denagan kontinyu bagi siswa yang bermasalah tampa melupakan siswa yang lain.

\section{Akhlak siswa terhadap guru}

Berdasarkan pengamatan yang dilakukan peneliti, ada beberapa siswa yang bersikap kurang baik terhadap guru, hal ini dapat terlihat siswa yang kurang peduli terhadap panggilan gurunya, ketika gurunya memberikan hukuman terhadap siswa yang bernama Sehan dan M. Hatta mereka berdua tidak terima atas hukuman yang diberikan gurunya.

Menurut Ermayuni (Guru Wali Kelas IV.B) mengatakan bahwa, sebelum diadakanya program pembinaan pendidikan karakter akhlak mulia 
siswanya ada empat orang yang berperilaku kurang sopan terhadap guru seperti membentah perkataan guru, dari keempat siswa yang bermasalah tersebut setelah mengikuti program pembinaan akhlak mulia hanya 2 orang lagi yang berperilaku kurang sopan terhadap guru.

Jadi dengan adanya program pembinaan pendidikan karakter akhlak mulia bagi siswa membawa dampak perubahan berperilaku biak dari perilaku yang kurang baik.

\section{Akhlak siswa terhadap lingkungan}

Menurut pengamatan yang dilakukan penulis pada mulanya siswa SD Negeri 2 Palapa masih terdapat beberapa siswa yang membuang sampah disembarang tempat, terliaht coret-coret meja dan dinding tembok sekolah. Kepedulian terhadap lingkungan yang dimaksud adalah kebersihan dan kesehatan lingkungan sekolah, seperti membersihkan kelas dan perkarangan sekolah, membuang sampah pada tempatnya, menanam bunga untuk keindahan sekolah.

Berdasarkan observasi penulis terdapat 5 orang siswa yang bermasalah, 8 orang yang selalu coretcoret meja, dinding, dan meja dijadikan gendang, 15 orang membunag sampah sembarangan, 3 orang yang sering merusak tanaman disekitar sekolah. Dari lima belas orang yang bermasalah ini setelah diberikan bimbingan dengan cara menanamkan rasa cinta lingkungan dan kebersihan dengan cara mengajak bakti sosial, memberi tugas membersihkan halaman, menanam bunga di taman depan kelas masingmasing, mengatur kelas dengan rapi dengan bimbigan wali kelas, dengan pembinaan secara terus menerus siswa tanpa terasa mengalami perubahan sikap menjadi baik.

Tarmizi (guru sekaligus Ketua Program Pembinaan Pendidikan Akhlak Mulia Negeri 2 Palapa Bandar Lampung) menerangkan bahwa kesadaran siswa terhadap kebersihan sudah berjalan tapi masih kurang maksimal, contoh piket umum tanpa ditegur mereka acuh tak acuh, mereka minta selalu diingatkan, buang sampah makanan sehabis jajan dikantin masih dibuang disembarang tempat kalau tidak di ingatkan, dan perhatian terhadap taman kurang seperti menyiram bunga tidak mau tanpa disuruh.

\section{Tanggung jawab siswa terhadap tugas}

Menurut Retno Safitri (guru SD Negeri 2 Palapa Bandar Lampung), masih ada beberapa siswanya yang tidak bertanggung jawab terhadap tugas seperti: malas mengerjakan PR, hingga guru harus marah karena tugas yang diberikan jarang dikerjakan. Menurut Azizah(guru SD Negeri 2 Palapa Bandar Lampung) masih ada siswa yang malas menjalankan tugas piketnya, dan pekerjaan yang diberikan guru disekolah seperti menggambar dan membuat peta.

Berdasarkan observasi penulis dikelas V.C terdapat 6 orang siswa yang bermasalah yang selalu tidak mengerjakan PR dan tugasnya dari guru. Dari 6 orang ini dalam kegiatan pembinaan karakter akhlak mulia dengan cara mengikut sertakan mereka lomba bercerita dan mengarang keteladanan nabi. Setelah siswa ikut kegiatan tersebut siswa terlihat adanya tanggungjawab terhadap tugasnya yang diberikan guru.

Berdasarkan data observasi dan wawancara penulis diatas, terlihat 
bahwa adanya peningkatan akhlak siswa setelah mengikuti program pembinaan pendidikan karakter akhlak mulia yaitu meningkatnya tanggungjawab siswa terhadap tugas-tugas yang diberikan oleh guru.

\section{Kepatuhan siswa terhadap kerapihan dan tata tertib}

Menurut Bustam Arifin (kepala SD Negeri 2 Palapa Bandar Lampung) menyatakan bahwa SD Negeri 2 palapa memiliki tata tertib yang harus dipatuhi oleh siswa, tata tertib tersebut seperti: Datang kesekolah sebelun bel berbunyi, berpakaian seragam dengan rapi, rambut tidak boleh gondrong, dilarang bolos, menjaga kebersihan lingkungan sekolah. Menurut Tarmizi (guru SD Negeri 2 Palapa Bandar Lampung), siswa dalam menjalankan tata tertib disekolah sangat kurang, tata tertib tersebut antara lain: datang terlambat, berambut gondrong, bolos dan lain sebagainya.

Berdasarkan hasil observasi penulis terdapat 9 siswa yang bermasalah dibimbing dengan latihan rutin kepanduan setiap hari Sabtu mereka menjadi patuh, sikapnya sopan, tertib datang kesekolah, dan rambutnya tidak gondrong lagi.

\section{Faktor-faktor Pendukung dan Penghambat}

Berdasarkan

penjelasan

sebelumnya bahwa, dalam pelaksanaan program kegiatan pembinaan pendidikan karakter akhlak mulia tidak sepenuhnya berjalan sesuai dengan apa yang telah diprogramkan kementrian pendidikan nasional direktorat jendral menejemen pendidikan dasar dan menengah dan program yang dibuat oleh sekolah. Hal tersebut dikarenakan adanya faktor yang mendukung dan penghambat dalam pelaksanaanya.

\section{Faktor Pendukung}

Faktor pendukung terlaksananya program ini adalah adanya undangundang dan Keputusan menteri pendidikan nasional yang mengatur tentang pembinaan karakter akhlak mulia, dukungan dari kepala sekolah dan dukungan guru dan staf tata usaha.

Undang-undang dan Keputusan menteri pendidikan nasional

Adapun salah satu mendorong adanya pembinaan pendidikan karakter akhlak mulia melalui kegiatan ekstrakurikuler adalah undang-undang sistem pendidikan nasional nomor 20 tahun 2003 dalam tujuan pendidikan nasional bab II pasal 3"Pendidikan Nasional berfungsi mengembangkan kemampuan dan membentuk watak serta peradaban bangsa yang bermartabat dalam rangka mencerdaskan kehidupan bangsa, bertujuan untuk mengembangkan potensi peserta didik agar menjadi manusia yang beriman dan bertakwa kepada Tuhan Yang Maha Esa, berakhlak mulia, sehat, berilmu, cakap kreatif, mandiri dan menjadi warga Negara yang demokratis serta bertanggung jawab" (Nata, 1997: 12).

Dan Permendiknas nomor 39 tahun 2008 tentang pembinaan kesiswaan disebutkan bahwa tujuan pembinaan kesiswaan antara lain adalah "Menyiapkan siswa agar menjadi warga masayarakat yang berakhlak mulia, demokratis, menghormati hak-hak azasi manusia dalam rangka mewujudkan masyarakat madani (civil society)" (Kemendiknas, 2010: 3). Serta keputusan menteri pendidikan nasional RI nomor 125/U/2002 tentang kalender 
pendidikan dan jam belajar efektif di sekolah, bab V pasal 9 ayat 2, dinyatakan bahwa: "Pada tengah semester 1 dan 2 sekolah melakukan kegiatan olahraga dan seni (Porseni), karyawisata, lomba kreativitas atau praktek pembelajaran yang bertujuan untuk mengembangkan bakat, kepribadian, prestasi, dan kreativitas siswa dalam rangka mengembangkan pendidikan anak seutuhnya" (Zainal \& Sujak, 2011: 70).

Dilanjutkan pada lampiran keputusan Mendiknas/U/2002 tanggal 31 Juli 2002 disebutkan "Liburan sekolah atau madrasah selama sebulan diisi dan dimanfaatkan untuk melaksanakan berbagai kegiatan yang diarahkan pada peningkatan akhlak mulia, pemahaman, pemdalaman, dan amaliah agama termasuk kegiatan ekstrakulikuler lainya yang bermuatan moral" (Zainal \& Sujak, 2011: 70).

\section{Kepala sekolah}

Secara implisit bahwa yang mendorong program kegiatan pembinaan pendidikan karakter akhlak mulia siswa di SD Negeri 2 Palapa Kecamatan Tanjung Karang Pusat adalah adanya dukungan dari kepala sekolah sebagai pemimpin (leader). Dukungan ini berdasarkan program kerja kepala sekolah sebagai acuan dalam pelaksanaan program pembinaan pendidikan akhlak mulia. Adapun program kerja tersebut adalah: (1) 1. Menciptakan rasa kekeluargaan di lingkungan sekolah; (2) Meningkatkan kerjasama dengan orang tua murid; (3) Meningkatkan mutu pendidikan; (4) Melengkapi sarana dan prasarana pendidikan; (5) Efektifitas dan efesiensi penggunaan sekolah; (6) Meningkatkan prestasi anak didik melalui akademik dan non akademik; (7) Meningkatkan profesionalisme guru dan tenaga kependidikan; (8) Mewujudkan peserta didik yang handal, mandiri, berprestasi, santun serta berakhlak mulia; dan (9) Meningkatkan mutu Iptek disekolah.

\section{Dukungan guru dan staf tata usaha}

Dalam pelaksanaan program pembinaan pendidikan karakter akhlak mulia yang ada di SD Negeri 2 Palapa dapat terlaksana tidak terlepas dari dukungan dan kerjasama kepala sekolah, dewan guru dan staf tata usaha. Dimana kepala sekolah memberikan tugas kepada guru dan tata usaha untuk bersama-sama mendukung, membina dan menjadi teladan bagi siswa-siswi SD Negeri 2 Palapa. Guru diwajibkan membuat prangkat mengajar dengan memasukan nilai-nilai karakter akhlak mulia, dan tata usaha mempersiapkan hal-hal yang dibutuhkan guna mendukung program pembinaan.

\section{Faktor Penghambat}

Berdasarkan penelitian ditemukan beberapa faktor penghambat dalam pengimplementasian program kegitan pembinaan pendidikan karakter akhlak mulia siswa di SD Negeri 2 Palapa Kecamatan Tanjung Karang Pusat Kota Bandar Lampung yaitu: (1) pembinaan belum maksimal; (2) sarana dan prasarana kurang memadai; dan (3) keungan yang belum mencukupi.

\section{Pembinaan belum maksimal}

Sesuai dengan pengamatan penulis dan pengamatan kepala sekolah bahwa pelaksanaan pembinaan terhadap karakter akhlak mulia siswa belum maksimal. Hal ini di ungkapakan oleh kepala sekolah SD Negeri 2 Palapa pada saat wawancara. Di sekolah SD Negeri 2 Palapa pelaksanaan program kegiatan pembinaan pendidikan karakter akhlak mulia di SD Negeri 2 Palapa tidak berjalan seluruhnya sesuai dengan 
program yang direncanakan, koordinasi dan kerjasama dewan guru dan komite kurang, sehingga kadang-kadang salah pengertian antara guru satu dan yang lainnya dalam menanamkan nilai-nilai akhlak mulia kepada siswa.

Dari hasil wawancara ini kepala sekolah menyarankan agar program ini berjalan dengan efektif perlu adanya kerjasama dari keseluruhan dewan guru dan orang tua murid untuk membiasakan dan menjadi figur teladan siswa berperilaku sesuai dengan nilainilai akhlak mulia.

\section{Sarana dan prasarana kurang memadai}

Dalam melakukan aktivitas
program
pendidikan karakter akhlak mulia, sarana kurang mendukung untuk tercapainya tujuan yang diharapkan. Sarana ibadah yang dimiliki oleh SD Negeri 2 Palapa tidak ada, ruang belajar bergantian kelas 1-3 dan kelas 6 masuk pagi dan kelas 4-5 masuk sore hari, ruang khusus untuk UKS tidak ada masih menempel diruang kepala sekolah, ruang WC yang tidak memadai, lapangan yang sempit.

\section{Keungan yang belum mencukupi}

Dana DIPA yang digunakan untuk membantu pelaksanaan pembinaan pendidikan karakter akhlak mulia yang diberikan oleh sekretariat Ditjen Mendikdasmen yang berjumlah Rp. 15.000,000,00 tidak mencukupi, kepala sekolah terpaksa menggunakan sebagian dana BOS dan iuran Komite sekolah agar pelaksanaan pembinaan pendidikan karakter akhlak mulia terus berjalan.

\section{SIMPULAN}

Berdasarkan pendapat dan literatur beberapa teori yang telah dikemukakan diatas atau bab-bab sebelumnya maka dapat disimpulkan bahwa implementasi program pembinaan pendidikan karakter akhlak mulia siswa melalui kegiatan ekstrakurikuler di SD Negeri 2 Palapa Kecamatan Tanjung Karang Pusat Kota Bandar Lampung sebagai berikut : Pertama, Implementasi pembinaan pendidikan karakter akhlak mulia siswa melalui kegiatan ekstrakurikuler di SD Negeri 2 Palapa Kecamatan Tanjung Karang Pusat Kota Bandar Lampung dilaksanakan melalui kegiatan Penerangan bahaya narkoba, outbond bagi siswa, pelaksanaan kebersihan dan kesehatan siswa, memperingati tahun baru islam, lomba bercerita dan mengarang ketauladanan Nabi, serta kegiatan pramuka. Dengan kegiatan ini terjadi peningkatan akhlak siswa berupa perubahan akhlak mulia terhadap guru/staf sekolah, sesama teman, peduli terhadap lingkungan, disiplin, tanggung jawab siswa terhadap tugas, berperilaku jujur, dan suka menabung.

Kedua, terdapat faktor pendukung dan penghambat terhadap pelaksanaan program pembinaan pendidikan karakter akhlak mulia siswa melalui kegiatan ekstrakurikuler di SD Negeri 2 Palapa Kecamatan Tanjung Karang Pusat Kota Bandar Lampung. Adapun faktor-faktor pendukung adalah: (a) Undang-undang sistem pendidikan nasional nomor 20 tahun 2003 dalam tujuan pendidikan nasional BAB II pasal 3 dan Keputusan menteri pendidikan nasional Nomor 39 tahun 2008 tentang pembinaan kesiswaan, keputusan menteri pendidikan nasional Nomor 125/U/2002 tentang kalender pendidikan dan jam belajar efektif di Sekolah, Bab V Pasal 9 ayat 2, dan lampiran Keputusan Mendiknas /U/2002 tanggal 31 Juli 2002; dan (b)Dukungan Kepala Sekolah, Tutor 
yang selalu menjadi motivator bagi siswa, sebagian guru yang telah membiasakan siswa berperilaku dengan akhlak mulia dan staf tata usaha yang membantu dalam administrasi.

Sedangkan faktor-faktor penghambat adalah: (a) Pembinaan belum maksimal terlaksana sesuai dengan prosedur perencanaan dan pelaksanaan program pembinaan; (b) Metode kegiatan dan strategi dalam penanaman nilai-nilai akhlak mulia masih belum terkonsep dalam program pembinaan; (c) Sarana dan prasarana kurang memadai; dan (d) Keuangan yang tidak mencukupi.

Pelaksanaan program pembinaan pendidikan karakter akhlak mulia, karena program kegiatan pembinaan pendidikan karakter akhlak mulia membantu mengembangkan kompetensi siswa dari segi kognitif, afektif, dan psikomotor, serta dapat mempermudah tercapainya visi dan misi sekolah

\section{DAFTAR RUJUKAN}

Ali, Muhammad. 2009. Pendidikan Untuk Pembangunan Nasional. Jakarta: PT. Imperial Bhakti Utama.

Aqib, Zainal dan Sujak. 2011. Panduan dan Aplikasi Pendidikan Karakter. Bandung: Yrama Widya.
Barnawi dan Arifin, M., 2012. Strategi dan Kebijakan Pembelajaran Pendidikan Karakter. Jogjakarta: Ar-Ruzz Media.

Kemendiknas, Petunjuk Teknis (JUKNIS) Bantuan Sosial Kegiatan Pembinaan Agama Dan Akhlak Mulia, Jakarta: Direktorat Jendral Menejemen Pendidikan Dasar dan Menengah, Tahun 2010

Kementrian Pendidikan Nasional direktorat Jenderal Menejemen Pendidikan Dasar dan Menengah, Pembinaan Akhlak mulia, Jakarta, 2010

Nata, Abudin. 1997. Filsafat Pendidikan Islam. Jakarta: Logos Wacana Ilmu.

Napitupulu, W.P., 2010. Pendidikan Nilai Gerakan Pramuka. Jakarta: Pustaka Tunas Media Kwartir Nasional.

Sauri, Sofwan. 2010. Membangun Karakter Bangsa Melalui Pembinaan Profesional Guru Berbasis Pendidikan Nilai. Jurnal Publikasi Ilmiah Pendidikan Umum Dan Nilai. Vol. 2 No. 2 : 1-78.

Tayibnapis, Farida Yusuf. 2000. Evaluasi Program. Jakarta: Rineka Cipta.

Undang-Undang Dasar Negara RI Tahun 1945, Jakarta, Sekretaris Jendral MPR RI, 2005 